\title{
CHARACTERIZATION AND TREATMENT OF EFFLUENTS FROM THE THREE MAIN STAGES OF NITROCELLULOSE PRODUCTION FOR EXPLOSIVES
}

\author{
L. F. Santos ${ }^{1}$, F.T. Silva ${ }^{2}$, T.C.B. Paiva ${ }^{3}$ \\ ${ }^{1}$ Chemical Engineering Department, Engineering school of Lorena, University of São Paulo, Lorena, Brazil \\ ${ }^{2}$ Biotechnology Department, Engineering school of Lorena, University of São Paulo, Lorena, Brazil \\ ${ }^{3}$ Biotechnology Department, Engineering school of Lorena, University of São Paulo, Lorena, Brazil
}

\begin{abstract}
This work shows the characterization of the effluents originating from the nitrocellulose industry and evaluates the combination of the chemical process with sludge activated for the treatment of these effluents. The delignification effluent presented color $(24.166 U C)$, TOC $(20.850 \mathrm{mg} / \mathrm{L})$, COD $(23.405 \mathrm{mg} / \mathrm{L})$ and BOD $(5.865 \mathrm{mg} / \mathrm{L})$ very high. The bleaching effluent presented residual chlorine content of $14.2 \mathrm{mg} / \mathrm{L}$. The nitration effluent presented $\mathrm{pH}$ of 0.85 and acidity index of $1.02 \%$, extremely low. These effluents presented toxicity to the bacteria Escherichia coli. The delignification effluent was submitted to the integration of processes: chemical followed by biological. The chemical treatment consisted in acidifying the effluent from the delignification stage at pH 1.2 to 1.8 with the nitration effluent, which is extremely acidic. This process allowed the coagulation/decanting of a large part of the organic materials present in the sample. The chemical treatment supernatant, after pH correction between 6.7 and 7.3, was submitted to biological treatment with activated sludge. To treat the bleaching effluent, a filtration system composed of a sand filter and an activated carbon filter was used. The treatment of the delignification effluent with the integrated process allowed reducing the color in $96.5 \%$, the TOC in $98.2 \%$, the COD in $98.7 \%$ and the BOD in $99.4 \%$. The filtration system (sand filter and activated carbon filter) made it possible to reduce the chlorine content of the bleaching effluent by around $90 \%$. Integrated treatment to treat delignification effluent; and physical, to treat the bleaching effluent, were effective for remediation of these effluents.
\end{abstract}

Keywords: Effluents, Treatment, Cellulose, Lignin, Bleaching, E. coli

\section{INTRODUCTION}

Environmental pollution is a global concern as many wastes are released daily in the environment. The launches occur because several production processes are inherently polluting [1-3]. For example, it is conceivable to mention the cotton process industry for nitrocellulose, which generates solid, liquid and gas waste, which, if not treated properly, it contribute to increase the environmental contamination [2,3]. Effluents from industry of lignocelluloses are also characterized by high toxicity, caused by compounds such chlorophenol, lignin derivatives, organic acids, acidic resins, dioxins and its derivatives [4,7]. In this regard, this work presents partial results performed to characterize and treat wastewater coming from the main nitrocellulose manufacturing stages in order to reduce as much as possible the pollution load present in these effluents.

\subsection{Nitrocellulose Production}

The nitrocellulose is obtained from the reaction of esterification of cellulose with mixture of nitric and sulfuric acid. The nitrocellulose is the principal raw material used in various lacquers, plastics, medicines and artificial leather. It is also used for the production of powder, propellant for guns, small weapons, and small missiles [4,5]. in the production of gunpowder, propellants, and dynamites based on nitroglycerin, which manufacture involves several steps, including the cotton mechanical separation, cotton delignification, bleaching of cotton delignificated, nitration of bleached pulp and stabilization of nitrocellulose, according to Figure $1[5,7]$.

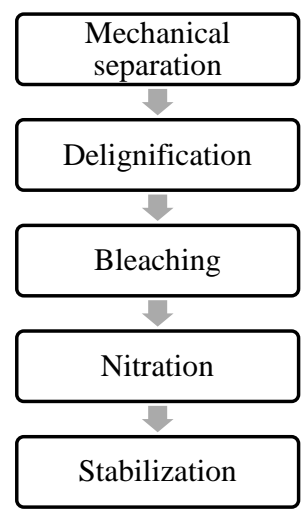

Fig 1 - Simplified flow chart of nitrocellulose production

\subsubsection{Mechanical Separation Process}

Normally, the cotton linters arrives at the company in bales of $200 \mathrm{Kg}$ and is subjected to the initial stage, which consists in the mechanical separation of impurities 
(cottonseeds, cotton bark, metallic bodies, silica, among others), using a magnetic defibrator. The solid wastes generated in this stage are properly designed by the company.

\subsubsection{Delignification Process}

After mechanical separation, cotton is subjected to step of delignification, with sodium hydroxide $(\mathrm{NaOH})$ solution of concentration of $25 \mathrm{~g} / \mathrm{L}$, temperature of $150^{\circ} \mathrm{C}$ and a pressure of about $6 \mathrm{Kgf} / \mathrm{cm}^{2}$, for approximately 80 minutes, in autoclaves (batch process). The delignificated cotton is washed thoroughly with water, generating, at this stage, an effluent rich in lignin, which has a dark color, a large amount of organic matter and is highly toxic. The waste in this phase was called of delignification effluent.

\subsubsection{Bleaching Process}

After the stage of pulp delignification, a small amount of lignin and other impurities such as metal ions, phenolic compounds, resins and other compounds containing chromophores groups from the lignocellulosic materials still remaining occluded in the cellulose fiber. The remaining lignin is responsible for brown tint-yellowish presented on the pulp. The removal, not only of the residual lignin, as well as of other impurities is necessary in order to obtain a pulp mill with a high level of whiteness and purity suitable for nitration [8]. To meet the demands of the process, the pulp is subjected to bleaching stage with sodium hypochlorite $(\mathrm{NaClO})$ concentrations close to $50 \mathrm{mg} / \mathrm{L}$; pressure of $6 \mathrm{Kgf} / \mathrm{cm}^{2}$ and temperature of $150^{\circ} \mathrm{C}$ (Batch Process). During this stage occurs reactions of oxidation and degradation of lignin and generates an effluent rich in free chlorine residual. The waste in this phase was called effluent of bleaching.

\subsubsection{Nitration Process}

The nitrocellulose is obtained by the reaction of nitration (esterification) of cellulose with the mix sulfonitric (nitric acid and sulfuric acid), in varying proportions, as the content of nitrogen required for the final product. This process is industrial and occurs in five reactors installed in series, which the temperature varies around $40^{\circ} \mathrm{C}$ and in ambient pressure. The flow of reagents is controlled to maintain the conditions required by the process. At this stage, there is variation in the composition of the mixture sulfonitric, with the consumption of nitric acid and water formation [9]. To minimize the problem of uniformity of the degree of substitution, it works with the excess nitrating mixture in relation to the pulp to be nitrated. In the process of nitration, it also occur parallel reactions caused by degradation of cellulose and hydrolysis, generating effluents containing organic compounds such as alcohols, olefins, aldehydes and nitrated compounds, which are extracted in the process through the stage of stabilization.

\subsubsection{Stabilization}

In the stabilization process of the nitrocellulose it is removed all unwanted compounds formed during the reaction of nitration. The stabilization is performed in two stages called acid cooking without pressure and acid cooking with pressure. At first, the nitrocellulose is subjected to boiling, the $98^{\circ} \mathrm{C}$ and the ambient pressure, in order to eliminate the excess acidity that involves the fiber; and in the second, the nitrocellulose is subjected to the boil at temperatures above $98^{\circ} \mathrm{C}$ and pressure around 2.5 $\mathrm{Kgf} / \mathrm{cm}^{2}$. The cooking time will vary according to the results presented by analysis of process control. The waste of this phase was called effluent from nitration.

\section{MATERIALS AND METHODS}

The samples were collected from all three stages of the manufacturing process of nitrocellulose, which generate liquid effluents, which were characterized and treated in accordance with the procedures described below [5.7].

\subsection{Collecting and Characterization of Samples}

The samples were collected in the most critical condition of eviction (concentrated effluents) and were characterized in $\mathrm{pH}$, total suspended solids (TSS), total fixed solids (TFS), total volatile solids (TVS), color, total organic carbon (TOC), chemical oxygen demand (COD), biochemical oxygen demand (BOD), acidity index and total chlorine free, before and after treatment, according to the analytical specific methods developed by the company itself and conventional techniques of analysis of wastewater [17].

\subsection{Acute Toxicity Test}

The effluent acute toxicity test was conducted by determining the growth inhibition of Escherichia coli (E. coli), modifying a method previously described by Jardim $[5,20]$. E. coli cultures were contaminated with different concentrations of effluent $(2 \% \mathrm{v} / \mathrm{v}, 6 \% \mathrm{v} / \mathrm{v}$ and $10 \% \mathrm{v} / \mathrm{v})$ and their growth was quantified using spectrophotometry $(400 \mathrm{~nm})$.

\subsection{Effluents Treatment Process}

Effluent of delignification: it was performed two processes: chemical treatment and chemical treatment followed by biological. The chemical treatment was to acidify the sample with the effluent from step of nitration until a $\mathrm{pH}$ between 1.2 to 1.8 . In the absence of this, it was used a solution of sulfuric acid, with a concentration within $30 \%$ to $50 \%$. This treatment was carried out in containers PVC, 200 liters, provided with a drain valve, distant $30 \mathrm{~cm}$ from the base (Figure 2a). The $\mathrm{pH}$ was monitored with $\mathrm{pHmeter}$ from the MICRONAL brand, mod. B-374. After flocculation and precipitation of a large part of the organic material present in the mixture ( 2 hours) were complete, the supernatant was separated by draining and then it was characterized. Integrated treatment consisted of subjecting the effluent treated chemically to treatment by activated sludge, in case semi-continuous. The biological treatment was performed in a reactor made of PVC, $50 \mathrm{~L}$, equipped with three valves (Figure 2b). The air supply was performed through compressors, which distribution inside the reactor was performed by means of jets with an intensity which, in 
addition to keeping the earth in microbial suspension, provided the minimum concentration of oxygen in the order of $8 \mathrm{mg} / \mathrm{L}$, with cycles of power/sleep every 6 hours. The time of rest for the sedimentation of the silt was 15 minutes. The departure of the reactor was amended with the silt ceded by the paper industry Kimberly-Clark Brazil - KCB.

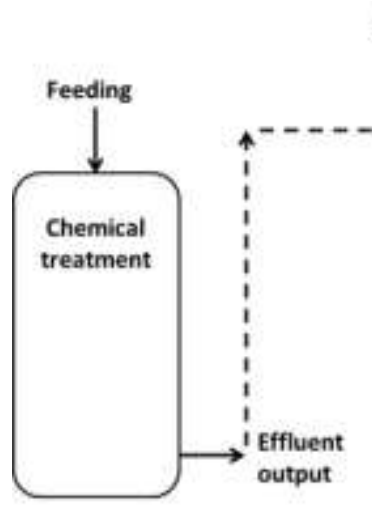

a)

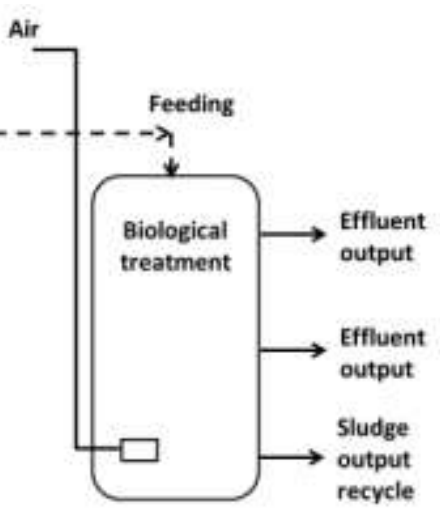

b)
Fig 2 - Scheme of chemical (a) and biological (b) reactors

Bleaching Effluent: the treatment of this effluent was performed by the filtration in two filters in series, made with PVC pipe of 6", a meter in length (Figure 3). The first filter has a layer $10 \mathrm{~cm}$ of pebbles and a $50 \mathrm{~cm}$ of fine sand and the second filter has a layer of $10 \mathrm{~cm}$ of pebbles and a layer of $60 \mathrm{~cm}$ activated charcoal, of a diameter between 2.54 to $3.87 \mathrm{~mm}$. Aimed to eliminate all the free chlorine residual present in the sample.

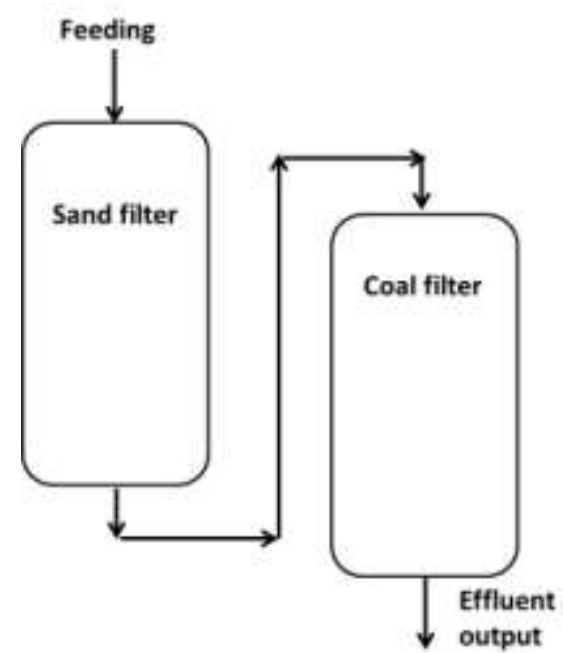

Fig 3 - Scheme of filtration system (physical treatment)

\section{RESULTS AND DISCUSSION}

Table 1 presents the results of the characterization of the raw effluents, collected in the most critical condition of eviction (concentrate).

The delignification effluent presented $\mathrm{pH}$ 12.7, TSS of $35.6 \mathrm{mg} / \mathrm{L}$, distributed in $15.8 \mathrm{mg} / \mathrm{L}$ of TFS and $19.8 \mathrm{mg} / \mathrm{L}$ of TVS. The composition of the inorganic fraction can be attributed mainly to sodium hydroxide, used in the process of delignification of cotton, and, to a lesser extent, by inorganic compounds present in raw cotton, which were determined as TFS.

The TVS $(19.8 \mathrm{~g} / \mathrm{L})$ was calculated as the difference between the amount of TSS and TFS and it is responsible for the high values of TOC $(20,853 \mathrm{mg} / \mathrm{L}), \mathrm{COD}(23,405 \mathrm{mg} / \mathrm{L})$ and BOD $(5,865 \mathrm{mg} / \mathrm{L})$ in the effluent. As the BOD is proportional to the concentration of organic compounds similar to aerobic bacteria, the eviction of this effluent without any treatment, in the receiving body would cause a high consumption of oxygen, causing the system to anaerobic conditions, thus causing the death of fishes and other organisms that depend on oxygen.

The organic fraction is responsible for the biggest problems related with effluent of this nature, like the intense color $(24,166 \mathrm{CU})$, which makes difficult the penetration of light rays in water courses and, consequently, affect the photosynthetic activity of aquatic flora; the high toxicity and the high demands in the chemical and biological oxygen, which can be attributed to the resins and the phenolic compounds derived from lignin [18].

Tabel 1 - Characterization of the raw effluents: delignifiction, bleaching and nitration

\begin{tabular}{|l|l|l|l|}
\hline \multirow{2}{*}{ Variables } & Effluents & \multicolumn{3}{|l|}{} \\
\cline { 2 - 4 } & Delignification & Bleaching & Nitration \\
\hline $\mathrm{pH}$ & 12.7 & 10.4 & 0.85 \\
\hline TSS [g/L] & 35.6 & 12.66 & 9.85 \\
\hline TFS [g/L] & 15.8 & 11.60 & 1.46 \\
\hline TVS [g/L] & 19.8 & 1.06 & 8.39 \\
\hline Color [CU] & 24,166 & 2.52 & 5.05 \\
\hline TOC [mg/L] & 20,853 & 273 & 105 \\
\hline COD [g/L] & 23,405 & ND & 74.8 \\
\hline BOD[g/L] & 5,865 & ND & 12.9 \\
\hline $\begin{array}{l}\text { Free Chlorine } \\
{[\mathrm{g} / \mathrm{L}]}\end{array}$ & $\mathrm{ND}$ & 14.2 & $\mathrm{ND}$ \\
\hline $\begin{array}{l}\text { Total acidy et } \\
\mathrm{H}_{2} \mathrm{SO}\end{array}$ & ND & ND & 1.02 \\
\hline
\end{tabular}

NT: Not Determined

The effluent of bleaching of pulp from cotton showed $\mathrm{pH}$ of 10.4 , TSS of $12.66 \mathrm{~g} / \mathrm{L}$, TFS of $11.60 \mathrm{~g} / \mathrm{L}$, TVS of $1.06 \mathrm{~g} / \mathrm{L}$, color of $2.52 \mathrm{CU}$, value of TOC $27 \mathrm{mg} / \mathrm{L}$ and chlorine concentration of $14.2 \mathrm{~g} / \mathrm{L}$. The organic compounds can be attributed to organochlorines derived from deslignificated cotton and the inorganic compounds of sodium hypochlorite used in the process. The large amount of free chlorine (14.2 $\mathrm{g} / \mathrm{L}$ ), present in the effluent of bleaching, caused the death of the organisms during incubation of the sample, hindering the determination of BOD. The excess of chlorine also interfered in the determination of COD, did not allow the reproduction of the results, possibly occurred reaction between chlorine and the reagents used in the analysis. However, it was not possible to determine the COT, which value was $273 \mathrm{mg} / \mathrm{L}$ that is quite low compared with the value found in the effluent of delignification $(20,853 \mathrm{mg} / \mathrm{L})$. The effluent from the stage of nitration of pulp presented $\mathrm{pH}$ of 0.85 . This $\mathrm{pH}$ is far below the standards of emission, 
which advocates a $\mathrm{pH}$ in the range of 5 to 9 , so that it can be launched at the receiving body. The TSS was $9.85 \mathrm{~g} / \mathrm{L}$, distributed in $1.46 \mathrm{~g} / \mathrm{L}$ TFS and $8.39 \mathrm{mg} / \mathrm{L}$ of TVS, color of $5.05 \mathrm{UC}$, TOC of $105 \mathrm{mg} / \mathrm{L}, \mathrm{COD}$ of $74.8 \mathrm{mg} / \mathrm{L}$, BOD of $12.9 \mathrm{mg} / \mathrm{L}$ and total acidity, reported in terms of $\mathrm{H}_{2} \mathrm{SO}_{4}$, $1.02 \%$. The value of BOD found is below the limits set by legislation (BOD $<60 \mathrm{mg} / \mathrm{L})$. The value of TOC found is really below from the one obtained from the effluent of delignification $(20,853 \mathrm{mg} / \mathrm{L})$. The low values of COD and BOD obtained reflect the low content of organic matter found in the effluent. The organic compounds of low molecular weight, including derived from soluble nitrocellulose in the middle, probably derived from the pulp and the inorganic acid mixture used in the process.

Table 2 presents the results obtained after the treatments performed.

Table 2 - Characteristcs of the delignification effluents: raw effluent, after treatment chemical and integrated

\begin{tabular}{|l|l|l|l|l|}
\hline Variables & $\begin{array}{l}\text { Raw } \\
\text { effluent }\end{array}$ & $\begin{array}{l}\text { After } \\
\text { chemical } \\
\text { treatment }\end{array}$ & $\begin{array}{l}\text { After } \\
\text { integrate } \\
\text { d } \\
\text { treatment }\end{array}$ & $\begin{array}{l}\text { Reducing } \\
(\%)\end{array}$ \\
\hline pH & 12.7 & 1.4 & 7.2 & $* *$ \\
\hline TSS [g/L] & 35.6 & 9.0 & 9.87 & 72.3 \\
\hline TFS [g/L] & 15.8 & 5.96 & 7.2 & 54.4 \\
\hline TVS [g/L] & 19.8 & 3.04 & 2.67 & 86.5 \\
\hline Color [CU] & 24,166 & 725 & 725 & 96.5 \\
\hline TOC [mg/L] & 20,853 & 1,069 & 377 & 98.2 \\
\hline COD [g/L] & 23,405 & 2,348 & 274 & 98.7 \\
\hline BOD[g/L] & 5,865 & 408 & 36 & 99.4 \\
\hline
\end{tabular}

*Comparison between the raw effluent and after treatment; **: complies with the legislation.

In Table 2 it can be observed that the biggest reductions were obtained with the chemical treatment, which resulted in the reduction of TSS in $72.3 \%$ of TFS at $62 \%$, TVS in $84 \%$ of color in $97 \%$ of TOC in $95 \%$ of COD in $90 \%$ and of BOD in $93 \%$. The comparison of the color reduction, is shown in Figure 4, which shows that a large part of the compounds chromophores was removed by this treatment.

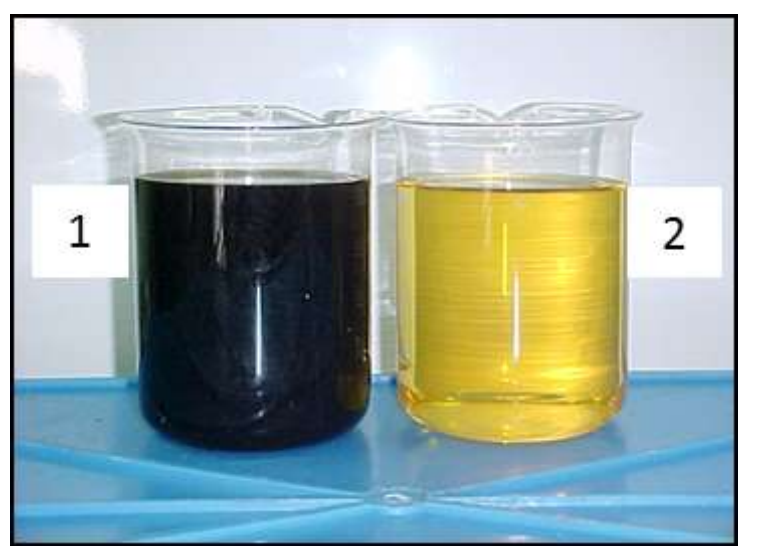

Fig 4 - Effluent: 1) before treatment and 2) after chemical treatment
The biological treatment with activated sludge adjusted the effluent in the legislation prevailing in the country. The integrated treatment reduced the COT by $98.2 \%$, COD in $98.7 \%$ and BOD in $99.4 \%$, which shows that the integrated process is highly promising for treatment of the effluent from delignification stage (Figure 5). During the biological treatment, there was no significant change of color, which may be due to poor removal of compounds of low molecular mass and the formation of new groups chromospheres during the biological treatment [19].

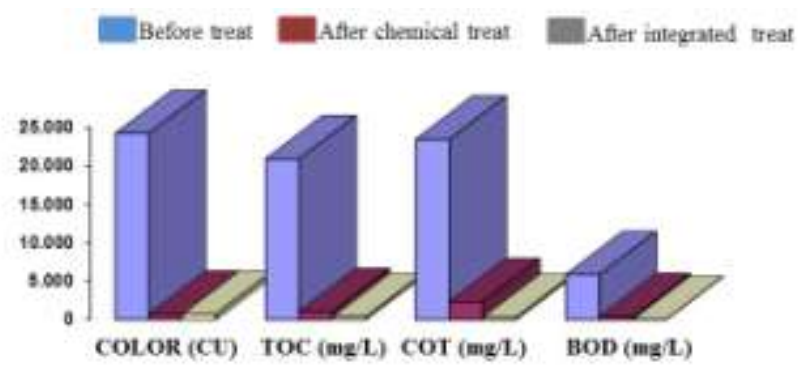

Fig 5 - Graphical representation of delignification effluent characteristics, before and after treatments.

The physical treatment of bleaching effluent made it possible to reduce the chlorine content of $14.2 \mathrm{~g} / \mathrm{L}$ to $1.43 \mathrm{~g} / \mathrm{L}$, implying a reduction of $90 \%$. This result shows that the process of filtration with bed of activated charcoal may be an alternative to reduce the chlorine content in the effluent of bleaching

The raw effluents, even in low concentrations, presented high toxicity, inhibiting $100 \%$ of E. coli growth (36 h) in a concentration of $2 \%(\mathrm{v} / \mathrm{v})$. It was observed that the chemical treatment was the main responsible for the reduction of toxicity of the delignification effluent. It was possible to treat by the activated sludge process the effluent chemically treated, there were no significant changes in the microorganisms of the system.

However, when the raw delignification effluent was submitted to the activated sludge process, the total immobilization of the microorganisms of the system was observed. This result ratified the importance of the chemical process as a preliminary treatment of delignification effluent. The physical treatment of the bleaching effluent allowed to reduce the chlorine content by $90 \%$, however, this reduction was not enough to eliminate the acute toxicity of this effluent.

\section{CONCLUSION}

The chemical treatment resulted in significant reductions in color, TOC, COD, BOD and acute toxicity. However, to ensure that the effluent could fit the patterns of eviction, it was necessary to submit it to the integrated process, i.e., complement the chemical treatment as the treatment by activated sludge.

The effluent of nitration of pulp presented low values of BOD, COD and TOC. However, its pH is extremely acid, out of range recommended by legislation. This characteristic 
has enabled their use for acidify the effluent of delignification, aiming to the precipitation of lignin, which, besides allowing the reuse, enabled reduce spending with its treatment.

The physical treatment, applied to the bleaching effluent, allowed to reduce the chlorine content by $90 \%$; However, this reduction was not significant to reduce toxicity in its totality.

\section{ACKNOWLEDGEMENT}

The authors thanks the Engineering School of Lorena, University of São Paulo (USP) for the financial this publication.

This article was partially presented in the XXVIII Interamerican Congress of Chemical Engineering Cuzco Perú (Oral presentation)

\section{REFERENCES}

[1]. WANG, Q.; YANG, Z. Industrial water pollution, water environment treatment, and health risks in China 2016. Environmental Pollution (2016), Disponível em http://dx.doi.org/10.1016/j.envpol.2016.07.011. Access: 28/08/2016

[2]. PAIVA, T.C.B. et al. Characterization of the pulp and bleaching effluents from a nitrocellulose industry and their environmental impact. In: 11 ISWPC, International symposium on wood and pulping chemistry. June, 2001. France. p. $11-14$.

[3]. MACKENZIE, L.D.; DAVID, A.C. Introduction to Environmental Engineering. 2 ed. McGrow-Hill. N.Y.: p. 645 - 722. 1991.

[4]. EL-DIWANI, G.; EL-IBIARI, N.N.; HAWASH, S.I. Treatment of hazardous wastewater contaminated by nitrocellulose. Journal of Hazardous Materials 167 (2009) 830-834.

[5]. SANTOS, L.F., Sistema de lodo ativado aplicado no tratamento de efluentes oriundos das etapas de fabricação de nitrocelulose. FAENQUIL. Lorena/SP. 103 p. (Dissertação de Mestrado). 2001

[6]. AMARAL, M. C. S.; ANDRADE, L. H.; LANGE, L. C.; Borges, C. P., Avaliação da biotratabilidade do efluente de branqueamento de polpa celulósica por processos aeróbios e anaeróbios. Eng. Sanit. Ambient. v.18. n 3. jul/set. p. 253-262. 2013.

[7]. SANTOS, L.F.; PAIVA, T.C.B.; SILVA, F.T. Tratamento de efluentes da fabricação de Nitrocelulose scale up. XX Congresso Brasileiro de Engenharia Química. Florianópolis/SC. 19 a 22 de outubro, 2014.

[8]. D'ALMEIDA, M.L.O.; PHILIPP, P.; BARSI, D. et al. Tecnologia de Fabricação de Pastas Celulósicas. Instituto de Pesquisas Tecnológicas (IPT). 2 ed. São Paulo: v.1. p. 169 319 e v. 2. p. $427-509.1988$.

[9]. TEMMING, H.; GRUNERT, H.; HUCKFELDT, H. Linters: Technical Information on Cotton Cellulose. English Translation of the 2 ed. Revised and Augmented German Edition. 1973.
[10]. SANT'ANNA, G. L. Jr. Tratamento biológico de efluentes: fundamentos e aplicações. Ed. Interciência. 2 ed. Rio de Janeiro/RJ. 418p. 2013.

[11]. TEIXEIRA, C. P. A. B.; JARDIM, W. F. Processos oxidativos avançados: conceitos teóricos, Caderno Temático 03. LQA/Unicamp. Campinas/SP. 2004. Disponível em http://lqa.iqm.unicamp.br/cadernos/caderno3.pdf. Acesso em: 31/03/2014.

[12]. BARRETO, M.R.; SOUZA, J.V.B.; SILVA, E.S.; SILVA, F.T.; PAIVA,T.C.B. Combined photo catalytic and fungal processes for the treatment of nitrocellulose industry wastewater, J. Hazard. Mater. 161 (2009) 1569-1573.

[13]. HAMMER, M.J.; HAMMER JR, M.J. Waste and wastewater technology. 6th. ed. Pearson Prentice Hall. Upper Saddle River, New Jersey. 2008. 553p

[14]. METCALF, L., EDDY, H.P. Wastewater Engineering : Treatment, Disposal and Reuse. 3th. ed. McGrow-Hill. 1991. $1334 \mathrm{p}$.

[15]. VON SPERLING, M. Lodos ativados: Princípios do tratamento biológico de águas residuárias. 1. ed. Belo Horizonte. Departamento Engenharia Sanitária e Ambiental (DESA). 1997. v. 4, 416 p.

[16]. BENTO, A.P.; SEVERINO, P.H.; PHILIPPI, L.S.; REGINATTO, V.; LAPOLLI, F.R. Caracterização da microfauna em estações de tratamento de esgotos do tipo lodos ativados: um instrumento de avaliação e controle. Engenharia Sanitária e Ambiental. vol. 10 - n 4. p 329 338. out./dez. 2005.

[17]. APHA - AMERICAN PUBLIC HEALTH ASSOCIATION AMERICAN WATER WORKS ASSOCIATION (AWWA), WATER ENVIROMENTAL FEDERATION (WEF), Standard Methods for the Examination of Water and Wastewater. 18 ed. American Public Health Association. Washington. 1992.

[18]. THOMPSON, G., SWAIN, J., FOSTER, C.F., KAY, M. The Treatment of Pulp and Paper Effluent : A Review. Bioresouce Tech. 77: 2001. p. 275 - 286.

[19]. MOUNTEER, A.H. et al. Estudo da remoção biológica da DQO recalcitrante de efluente de branqueamento de polpa kraft de eucalipto. In: 35o Congresso e exposição anual de celulose e papel. São Paulo/SP. 14 a 17 de outubro, 2002.

[20]. JARDIM, W.F., PASQUINI, C., GUIMARÃES, J.R. Short-Term Toxicity Test Using Escherichia coli : Monitoring $\mathrm{CO} 2$ by Flow Injection Analysis. Water Research. 24: 1990. p. $351-354$. 